
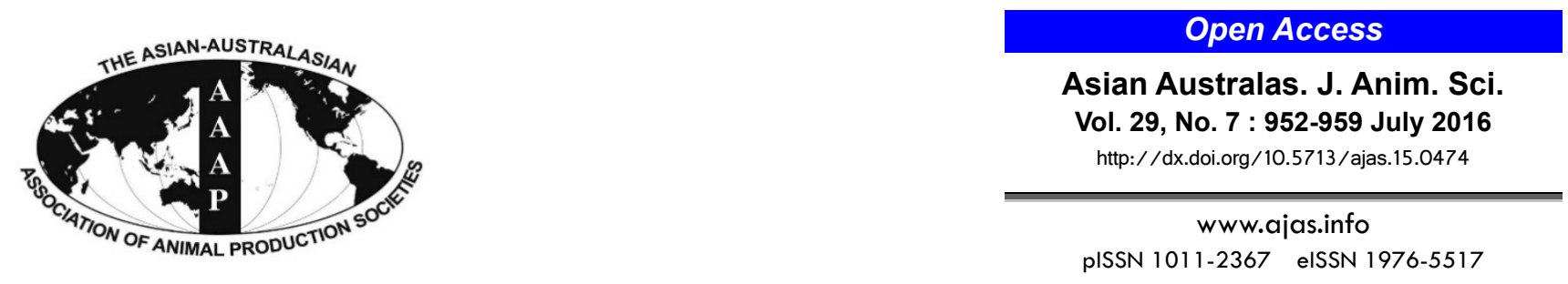

\title{
In vitro Screening of Essential Oil Active Compounds for Manipulation of Rumen Fermentation and Methane Mitigation
}

\author{
M. Joch ${ }^{1, *}$, L. Cermak ${ }^{1}$, J. Hakl ${ }^{2}$, B. Hucko, D. Duskova ${ }^{1}$, and M. Marounek ${ }^{1}$ \\ Department of Microbiology, Nutrition and Dietetics, Faculty of Agrobiology, Food and Natural Resources, \\ Czech University of Life Sciences, Prague 16521, Czech Republic
}

\begin{abstract}
The objective of this study was to investigate the effects of 11 active compounds of essential oils (ACEO) on rumen fermentation characteristics and methane production. Two trials were conducted. In trial 1, ACEO (eugenol, carvacrol, citral, limonene, 1,4-cineole, $p$-cymene, linalool, bornyl acetate, $\alpha$-pinene, and $\beta$-pinene) at a dose of $1,000 \mu \mathrm{L} / \mathrm{L}$ were incubated for $24 \mathrm{~h}$ in diluted rumen fluid with a $70: 30$ forage:concentrate substrate $(16.2 \%$ crude protein; $36.6 \%$ neutral detergent fiber). Three fistulated Holstein cows were used as donors of rumen fluid. The reduction in methane production was observed with nine ACEO (up to $86 \%$ reduction) compared with the control $(\mathrm{p}<0.05)$. Among these, only limonene, 1,4 -cineole, bornyl acetate, and $\alpha$-pinene did not inhibit volatile fatty acid (VFA) production, and only bornyl acetate produced less methane per mol of VFA compared with the control ( $\mathrm{p}<0.05$ ). In a subsequent trial, the effects on rumen fermentation and methane production of two concentrations (500 and 2,000 $\mu \mathrm{L} / \mathrm{L})$ of bornyl acetate, the most promising ACEO from the first trial, were evaluated using the same in vitro incubation method that was used in the first trial. In trial 2 , monensin was used as a positive control. Both doses of bornyl acetate decreased $(\mathrm{p}<0.05)$ methane production and did not inhibit VFA production. Positive effects of bornyl acetate on methane and VFA production were more pronounced than the effects of monensin. These results confirm the ability of bornyl acetate to decrease methane production, which may help to improve the efficiency of energy use in the rumen. (Key Words: Essential Oil Active Compounds, Methane Production, Volatile Fatty Acid Production, Rumen Fermentation, Bornyl Acetate)
\end{abstract}

\section{INTRODUCTION}

In ruminants, methane is a natural by-product of anaerobic respiration, and its production serves as the principal electron sink in the rumen. Methane represents a significant loss of dietary energy (Beauchemin et al., 2008). The ultimate aims in manipulating ruminal fermentation are to maximize the efficiency of feed utilization and increase ruminant productivity. Therefore, considerable research effort has focused on methods to modify ruminal fermentation. Antibiotic ionophores have been very

\footnotetext{
* Corresponding Author: M. Joch. Tel: +42-0-22-438-2669, Fax:+42-0-22-438-2760, E-mail: joch@af.czu.cz

${ }^{1}$ Institute of Animal Science, Prague Uhrineves 10400, Czech Republic.

2 Department of Forage Crops and Grassland Management, Czech University of Life Sciences, Prague 16521, Czech Republic. Submitted Jun. 1, 2015; Revised Sept. 17, 2015; Accepted Oct. 8, 2015
}

successful in reducing energy and protein losses (Nagaraja et al., 1997). However, the use of antibiotics in animal feed is facing reduced social acceptance because of the appearance of residues and resistant strains of bacteria; thus, their use has been banned in the European Union since January 2006 (Directive 1831/2003/CEE, European Commission, 2003).

The use of plant secondary metabolites as rumen modifiers seems to be a better approach since these are natural products that might be environment-friendly and have a better acceptance among consumers (Agarwal et al., 2009). Previous studies showed that some essential oils and their compounds had potential to enhance rumen fermentation (Benchaar et al., 2007; Castillejos et al., 2007). However, the effects reported in the literature are variable and contradictory. Essential oils are complex mixtures of several individual compounds, which make it difficult to elucidate the precise mechanism of action on rumen 
fermentation and their use as feed additives (Busquet et al., 2005a). Compared with essential oils, only a few individual active compounds of essential oils (ACEO) have been tested for their effects on rumen fermentation and methane production (Castillejos et al., 2006; Klevenhusen et al., 2012).

Therefore, the objective of the present study was to evaluate the effects of 11 ACEO (eugenol, carvacrol, citral, limonene, 1,4-cineole, $p$-cymene, linalool, bornyl acetate, $\alpha$-pinene, and $\beta$-pinene) on rumen fermentation and methane production.

\section{MATERIALS AND METHODS}

\section{Experimental design and treatment}

In trial 1 , the effects of 11 ACEO (eugenol [99\% purity], carvacrol [98\% purity], citral [95\% purity], limonene [96\% purity], 1,4-cineole [85\% purity], $\gamma$-terpinene [97\% purity], $p$-cymene [99\% purity], linalool [97\% purity], bornyl acetate [95\% purity], $\alpha$-pinene [98\% purity], and $\beta$-pinene [99\% purity]), which were provided by Sigma-Aldrich Chemical (Sigma-Aldrich, St. Louis, MO, USA), on rumen fermentation and methane production were evaluated using an in vitro batch fermentation system. The compounds $(1,000 \mu \mathrm{L} / \mathrm{L})$ were added directly to the incubation bottles, no solvent was used. In trial 1, 108 serum bottles (12 treatments $\times 3$ cows $\times 3$ replications) were used.

In trial 2 , the effects of two concentrations (500 and $2,000 \mu \mathrm{L} / \mathrm{L}$ ) of bornyl acetate, the most promising ACEO from trial 1, were evaluated using the same in vitro incubation method as in the first trial. In trial 2, monensin (10 mg/L; M5273, Sigma-Aldrich Chemical, USA) was used as a positive control. Monensin $(15 \mathrm{mg})$ was dissolved in $1.5 \mathrm{~mL}$ of ethanol, and $0.15 \mathrm{~mL}$ of stock solution was added to the bottle to achieve a final concentration of 10 $\mathrm{mg} / \mathrm{L}$ of culture fluid. In trial 2,36 serum bottles (4 treatments $\times 3$ cows $\times 3$ replications) were used. In both trials, controls were included in parallel that contained neither ACEO nor monensin.

\section{Ruminal inoculum, substrate, and in vitro incubation}

Ruminal inoculum was obtained $2 \mathrm{~h}$ after the morning feeding from three ruminally fistulated Holstein dairy cows. In trial 1, all three cows were in lactation, whereas in trial 2, two cows were in lactation and one was in the early dry period. Cows were fed ad libitum. The total mixed ration (TMR) of lactating cows was composed (percent dry matter) of maize silage $(35.5 \%)$, alfalfa silage $(16 \%)$, concentrate mixture $(41 \%)$, and brewers grain $(7.5 \%)$. In trial 2 , TMR of early dry cow was composed (percent dry matter) of maize silage $(39 \%)$, alfalfa silage $(18 \%)$, concentrate mixture $(22 \%)$, grass hay $(17 \%)$, and wheat straw (4\%). The rumen content from each cow was brought separately to the laboratory in vacuum flasks, strained through one layer of cheesecloth, and used within $20 \mathrm{~min}$.

The experimental substrate consisted of three feeds (alfalfa silage, maize silage, and concentrate) in a ratio of 350:350:300 mg on a dry matter basis.

In vitro fermentations were conducted in serum bottles. Briefly, $1 \mathrm{~g}$ of dried substrate with additives was incubated in $300-\mathrm{mL}$ capacity gas-tight serum bottles containing 100 $\mathrm{mL}$ of phosphate-bicarbonate buffer according to McDougall (1948) with modifications (per liter of distilled water: $9.8 \mathrm{~g} \mathrm{NaHCO}_{3} ; 7 \mathrm{~g} \mathrm{Na}_{2} \mathrm{HPO}_{4} \cdot 12 \mathrm{H}_{2} \mathrm{O}$; $0.6 \mathrm{~g}$ urea; 0.6 $\mathrm{g} \mathrm{KCl} ; 0.03 \mathrm{~g} \mathrm{CaCl}_{2} ; 0.06 \mathrm{~g} \mathrm{MgSO}_{4} \cdot 7 \mathrm{H}_{2} \mathrm{O}$ ) and $50 \mathrm{~mL}$ rumen fluid. Fermentation bottles without additives, but containing $1 \mathrm{~g}$ of the substrate, were used as a control. Bottles with substrate, additives, and incubation medium were flushed with $\mathrm{CO}_{2}$ and incubated for $24 \mathrm{~h}$ at $39^{\circ} \mathrm{C}$ after sealing with a butyl rubber stopper and aluminum caps.

\section{Sampling and analysis}

After $24 \mathrm{~h}$ incubation, the gas in the headspace of the bottles was analyzed for methane using a gas chromatograph (GC 82F, Labio, Prague, Czech Republic) equipped with a flame ionization detector and capillary column. A sample of $0.1 \mathrm{~mL}$ of gas was injected using a 1 mL Sample-Lock syringe (Hamilton, Reno, NV, USA).

After opening the incubation flask, $\mathrm{pH}$ was measured ( $\mathrm{pH} 700$, Eutech Instruments, Singapore, Singapore), and 2 $\mathrm{mL}$ of incubation medium was collected and centrifuged for $1 \mathrm{~min}$ at $13,000 \mathrm{rpm}$. Supernatant $(64 \mu \mathrm{L})$ was mixed with $736 \mu \mathrm{L}$ of $\mathrm{H}_{2} \mathrm{O}, 30 \mu \mathrm{L}$ of internal standard (2-ethylbutyric acid), and $100 \mu \mathrm{L}$ of formic acid and then centrifuged again for $1 \mathrm{~min}$ at $13,000 \mathrm{rpm}$. Samples were stored at $8^{\circ} \mathrm{C}$ until volatile fatty acids (VFA) analysis using gas chromatography on a Labio GC 82F equipped with a flame ionization detector and capillary column, and with hydrogen as the carrier gas. Briefly, $1 \mu \mathrm{L}$ was injected; the injector temperature was $200^{\circ} \mathrm{C}$, and the inlet pressure was $50 \mathrm{kPa}$. The temperature program was $75^{\circ} \mathrm{C}$ at the start of the injection, increased $5^{\circ} \mathrm{C} / \mathrm{min}$ until $80^{\circ} \mathrm{C}$ (kept for $1 \mathrm{~min}$ ), and then increased $6^{\circ} \mathrm{C} / \mathrm{min}$ until $128^{\circ} \mathrm{C}$ (kept for $10 \mathrm{~min}$ ). The detector temperature was $200^{\circ} \mathrm{C}$.

\section{Chemical analysis}

Samples of alfalfa and maize silage were dried in a forced air oven at $65^{\circ} \mathrm{C}$. Subsequently, silages and concentrate samples were ground to pass a 1-mm sieve. Ground samples were stored for chemical analyses. The chemical composition of substrate was determined according to AOAC (2005) for crude protein (as $6.25 \times \mathrm{N}$ ), starch, and ash, and according to AOAC (1995) for ether extracts. The neutral detergent fiber (NDF) and acid detergent fiber (ADF) were measured according to the method of Mertens (2002). The ADF and NDF were 
assayed with a heat stable amylase and expressed exclusive of residual ash.

\section{Statistical analysis}

All statistical analyses were conducted using Statistica 9.1 (StatSoft, Tulsa, OK, USA). Data were analyzed using two-way analysis of variance using a mixed model where ACEO (treatment) was considered as the fixed factor and the cow as the random factor. The effects of ACEO on methane production, VFA production and $\mathrm{pH}$ were compared with those of the control using the Dunnett test $(\mathrm{p}<0.05)$.

\section{RESULTS}

The overall chemical composition of the experimental substrate and the chemical composition of individual feeds are presented in Table 1.

Results of the effects of ACEO $(1,000 \mu \mathrm{L} / \mathrm{L})$ on in vitro methane production and rumen fermentation characteristics are presented in Table 2 and 3. Among the ACEO investigated, only carvacrol treatment resulted in a $\mathrm{pH}$ change compared with the control $(\mathrm{p}<0.05)$. Nine ACEO decreased methane production compared with the control $(\mathrm{p}<0.05)$. At the treatment dose of $1,000 \mu \mathrm{L} / \mathrm{L}$, the most pronounced inhibition of methane production was noted for carvacrol, with the magnitude of inhibition decreasing in the following order: carvacrol $(-86 \%)$, citral $(-44 \%)$, bornyl acetate $(-38 \%), \quad \alpha$-pinene $(-29 \%), \quad \beta$-pinene $(-28 \%)$, eugenol $(-24 \%)$, linalool $(-24 \%)$, limonene $(-23 \%)$ and 1,4-cineole $(-22 \%)$. Total VFA concentration was decreased $(\mathrm{p}<0.05)$ by eugenol, carvacrol, citral, $p$-cymene, linalool,
Table 1. Chemical composition of alfalfa silage, maize silage, concentrate, and experimental substrate (\% DM, except DM: \%)

\begin{tabular}{lcccc}
\hline & $\begin{array}{c}\text { Alfalfa } \\
\text { silage }\end{array}$ & $\begin{array}{c}\text { Maize } \\
\text { silage }\end{array}$ & Concentrate & Substrate \\
\hline Dry matter & 41.1 & 29.9 & 89.1 & 100.0 \\
Crude protein & 18.1 & 7.8 & 23.6 & 16.2 \\
Ether extract & 1.6 & 3.9 & 7.9 & 4.3 \\
Starch & - & 37.6 & 33.8 & 23.3 \\
NDF & 47.3 & 41.9 & 17.8 & 36.6 \\
ADF & 40.0 & 22.4 & 7.8 & 24.2 \\
Ash & 10.5 & 4.2 & 11.3 & 8.5 \\
\hline
\end{tabular}

DM, dry matter; NDF, neutral detergent fiber; ADF, acid detergent fiber.

and $\beta$-pinene. The addition of ACEO did not change $(p>0.05)$ the molar proportion of acetate, with the exception of citral (Table 3 ). The addition of eugenol, citral, $p$-cymene, and linalool decreased $(p<0.05)$ the molar proportion of propionate and increased $(p<0.05)$ that of butyrate. $\gamma$ Terpinene also increased $(\mathrm{p}<0.05)$ the molar proportion of butyrate, but without an effect on the molar proportion of propionate. The acetate:propionate ratio increased $(\mathrm{p}<0.05)$ only upon the addition of eugenol, citral, and $p$-cymene. The effect of the cow was significant for all evaluated fermentation products, and as a random factor, contributed to total variability in the range of $18 \%$ to $73 \%$ (data not shown).

Results of the effects of bornyl acetate (500 and 2,000 $\mu \mathrm{L} / \mathrm{L})$ and monensin $(10 \mathrm{mg} / \mathrm{L})$ on in vitro methane production and rumen fermentation characteristics are presented in Table 4 and 5. Neither bornyl acetate nor monensin affected $\mathrm{pH}$ compared with the control $(\mathrm{p}>0.05)$. Relative to the control, the addition of bornyl acetate at 500

Table 2. Effect of ACEO on $\mathrm{pH}$, methane production and total VFA concentrations in in vitro rumen fermentation

\begin{tabular}{|c|c|c|c|c|c|c|}
\hline \multirow{2}{*}{ Treatment } & \multicolumn{2}{|c|}{ Dosage } & \multirow{2}{*}{$\mathrm{pH}$} & \multicolumn{3}{|c|}{ Fermentation product } \\
\hline & $(\mu \mathrm{L} / \mathrm{L})$ & $(\mathrm{mg} / \mathrm{L})$ & & Methane (mmol/L) & $\mathrm{VFA}(\mathrm{mmol} / \mathrm{L})$ & Methane $(\mathrm{mmol} / \mathrm{mol}$ VFA \\
\hline Control & 0 & 0 & 6.45 & 17.3 & 102.1 & 175.1 \\
\hline Eugenol & 1,000 & 1,067 & 6.55 & $13.1^{*}$ & $78.1^{*}$ & 171.7 \\
\hline Carvacrol & 1,000 & 976 & $6.78^{*}$ & $2.4^{*}$ & $51.4^{*}$ & $47.0^{*}$ \\
\hline Citral & 1,000 & 888 & 6.57 & $9.7 *$ & $77.3^{*}$ & $126.0 *$ \\
\hline Limonene & 1,000 & 844 & 6.53 & $13.4^{*}$ & 90.0 & 151.9 \\
\hline 1,4-Cineole & 1,000 & 887 & 6.50 & $13.6^{*}$ & 94.3 & 149.6 \\
\hline$\gamma$-Terpinene & 1,000 & 850 & 6.52 & 14.2 & 89.3 & 162.8 \\
\hline p-Cymene & 1,000 & 860 & 6.54 & 14.0 & $86.1^{*}$ & 167.9 \\
\hline Linalool & 1,000 & 870 & 6.56 & $13.2 *$ & $86.0^{*}$ & 157.0 \\
\hline Bornyl acetate & 1,000 & 986 & 6.53 & $10.8^{*}$ & 91.1 & $122.4^{*}$ \\
\hline$\alpha$-Pinene & 1,000 & 858 & 6.51 & $12.3^{*}$ & 89.5 & 141.4 \\
\hline$\beta$-Pinene & 1,000 & 866 & 6.55 & $12.4^{*}$ & $86.5^{*}$ & 148.7 \\
\hline \multicolumn{7}{|l|}{ Statistics } \\
\hline SEM & & & 0.02 & 4.49 & 1.79 & 5.13 \\
\hline \multirow[t]{2}{*}{ p-value } & Treatment & & $<0.001$ & $<0.001$ & $<0.001$ & $<0.001$ \\
\hline & Cow & & $<0.001$ & $<0.001$ & $<0.001$ & $<0.001$ \\
\hline
\end{tabular}

ACEO, active compounds of essential oils; VFA, volatile fatty acids; SEM, standard error of the means.

* Means within a column differ from control $(\mathrm{p}<0.05)$. 
Table 3. Effect of ACEO on individual VFA molar proportions and acetate to propionate molar ratio

\begin{tabular}{|c|c|c|c|c|c|c|}
\hline \multirow[b]{2}{*}{ Treatment } & \multicolumn{2}{|c|}{ Dosage } & \multicolumn{4}{|c|}{ Fermentation product } \\
\hline & $(\mu \mathrm{L} / \mathrm{L})$ & $(\mathrm{mg} / \mathrm{L})$ & $\begin{array}{c}\text { Acetate } \\
(\mathrm{mol} / 100 \mathrm{~mol})\end{array}$ & $\begin{array}{c}\text { Propionate } \\
(\mathrm{mol} / 100 \mathrm{~mol})\end{array}$ & $\begin{array}{c}\text { Butyrate } \\
(\mathrm{mol} / 100 \mathrm{~mol})\end{array}$ & $\mathrm{A}: \mathrm{P}$ \\
\hline$\overline{\text { Control }}$ & 0 & 0 & 52.8 & 27.1 & 11.4 & 2.13 \\
\hline Eugenol & 1,000 & 1,067 & 53.7 & $18.4^{*}$ & $17.7^{*}$ & $3.04 *$ \\
\hline Carvacrol & 1,000 & 976 & 53.9 & 24.6 & 11.1 & 2.20 \\
\hline Citral & 1,000 & 888 & $55.2 *$ & $16.4^{*}$ & $17.4^{*}$ & $3.54 *$ \\
\hline Limonene & 1,000 & 844 & 52.9 & 25.0 & 12.5 & 2.14 \\
\hline 1,4-Cineole & 1,000 & 887 & 52.4 & 27.3 & 11.4 & 1.94 \\
\hline$\gamma$-Terpinene & 1,000 & 850 & 52.8 & 24.4 & $13.0^{*}$ & 2.18 \\
\hline p-Cymene & 1,000 & 860 & 54.1 & $21.4 *$ & $14.5^{*}$ & $2.56^{*}$ \\
\hline Linalool & 1,000 & 870 & 51.2 & $23.1^{*}$ & $15.2 *$ & 2.27 \\
\hline Bornyl acetate & 1,000 & 986 & 51.5 & 26.6 & 11.8 & 1.95 \\
\hline$\alpha$-Pinene & 1,000 & 858 & 51.8 & 27.7 & 11.7 & 1.89 \\
\hline$\beta$-Pinene & 1,000 & 866 & 51.8 & 26.4 & 12.5 & 1.98 \\
\hline \multicolumn{7}{|l|}{ Statistics } \\
\hline SEM & & & 0.30 & 0.41 & 0.24 & 0.06 \\
\hline \multirow[t]{2}{*}{ p-value } & Treatment & & $<0.001$ & $<0.001$ & $<0.001$ & $<0.001$ \\
\hline & Cow & & $<0.001$ & $<0.001$ & $<0.001$ & $<0.001$ \\
\hline
\end{tabular}

ACEO, active compounds of essential oils; VFA, volatile fatty acids; A:P, acetate:propionate; SEM, standard error of the means.

* Means within a column differ from control $(\mathrm{p}<0.05)$.

and $2,000 \mu \mathrm{L} / \mathrm{L}$ decreased $(\mathrm{p}<0.05)$ methane production by $24 \%$ and 39\%, respectively. Monensin decreased $(\mathrm{p}<0.05)$ methane production by $22 \%$. Total VFA production was not affected $(\mathrm{p}>0.05)$ by bornyl acetate or monensin. Bornyl acetate $(500$ and $2,000 \mu \mathrm{L} / \mathrm{L})$ decreased $(\mathrm{p}<0.05)$ the molar proportion of acetate and butyrate, and the $2,000 \mu \mathrm{L} / \mathrm{L}$ dose also increased the molar proportion of propionate. Monensin increased the molar proportion of acetate and decreased the molar proportion of butyrate, compared with the control. The effect of the cow was significant for all evaluated fermentation products, and as a random factor, contributed to total variability in the range of $52 \%$ to $88 \%$ (data not shown).

\section{DISCUSSION}

The selective inhibition of specific groups of microbes, such as methanogens, protozoa, and hyper-ammonia- producing bacteria, is regarded as the mode of action of essential oils and is applicable for the manipulation of rumen fermentation (Calsamiglia et al., 2007). Although essential oils are effective against both gram-positive and gram-negative bacteria, the outer membrane of gramnegative bacteria seems to provide some degree of protection (Davidson and Naidu, 2000), making them less sensitive to essential oils. Thus, shifts in bacterial composition may reduce overall bacterial fermentative activity and selectively favor less essential oil-susceptible gram-negative bacteria (Klevenhusen et al., 2012). In the rumen, gram-positive bacteria are largely acetate- and butyrate-producing bacteria, while Gram-negative bacteria are generally propionate-producing bacteria (Stewart et al., 1997).

The substrate content of crude protein and NDF was in accordance with the findings of Klevenhusen et al. (2012), who showed in meta-analysis of 20 studies that the content

Table 4. Effect of bornyl acetate and monensin on $\mathrm{pH}$, methane production and total VFA concentrations in in vitro rumen fermentation

\begin{tabular}{|c|c|c|c|c|c|c|}
\hline \multirow{2}{*}{ Treatment } & \multicolumn{2}{|c|}{ Dosage } & \multirow{2}{*}{$\mathrm{pH}$} & \multicolumn{3}{|c|}{ Fermentation product } \\
\hline & $(\mu \mathrm{L} / \mathrm{L})$ & $(\mathrm{mg} / \mathrm{L})$ & & Methane $(\mathrm{mmol} / \mathrm{L})$ & $\mathrm{VFA}(\mathrm{mmol} / \mathrm{L})$ & Methane (mmol/mol VFA) \\
\hline Control & 0 & 0 & 6.61 & 19.6 & 78.6 & 255.9 \\
\hline Monensin & & 10 & 6.58 & $15.3^{*}$ & 80.1 & $201.3^{*}$ \\
\hline \multirow[t]{2}{*}{ Bornyl acetate } & 500 & 493 & 6.64 & $14.9 *$ & 73.6 & $203.0^{*}$ \\
\hline & 2,000 & 1,972 & 6.62 & $12.0^{*}$ & 80.8 & $147.0^{*}$ \\
\hline \multicolumn{7}{|l|}{ Statistics } \\
\hline SEM & & & 0.02 & 0.65 & 2.71 & 8.69 \\
\hline \multirow[t]{2}{*}{ p-value } & Treatment & & 0.515 & $<0.001$ & 0.429 & $<0.001$ \\
\hline & Cow & & $<0.001$ & $<0.001$ & $<0.001$ & $<0.001$ \\
\hline
\end{tabular}

VFA, volatile fatty acids; SEM, standard error of the means.

* Means within a column differ from control $(\mathrm{p}<0.05)$. 
Table 5. Effect of bornyl acetate and monensin on individual VFA molar proportions and acetate to propionate molar ratio

\begin{tabular}{|c|c|c|c|c|c|c|}
\hline \multirow{2}{*}{ Treatment } & \multicolumn{2}{|c|}{ Dosage } & \multicolumn{4}{|c|}{ Fermentation product } \\
\hline & $(\mu \mathrm{L} / \mathrm{L})$ & $(\mathrm{mg} / \mathrm{L})$ & Acetate $(\mathrm{mol} / 100 \mathrm{~mol})$ & Propionate $(\mathrm{mol} / 100 \mathrm{~mol})$ & Butyrate $(\mathrm{mol} / 100 \mathrm{~mol})$ & A:P \\
\hline Control & 0 & 0 & 59.4 & 20.9 & 12.9 & 2.95 \\
\hline Monensin & & 10 & $61.5 *$ & 21.3 & $10.8 *$ & 2.98 \\
\hline \multirow[t]{2}{*}{ Bornyl acetate } & 500 & 493 & $56.9 *$ & 22.1 & $10.3^{*}$ & 2.64 \\
\hline & 2,000 & 1,972 & $51.9^{*}$ & $25.1^{*}$ & $9.8^{*}$ & $2.08^{*}$ \\
\hline \multicolumn{7}{|l|}{ Statistics } \\
\hline SEM & & & 0.84 & 0.58 & 0.33 & 0.10 \\
\hline \multirow[t]{2}{*}{ p-value } & Treatment & & $<0.001$ & $<0.001$ & $<0.001$ & $<0.001$ \\
\hline & Cow & & $<0.001$ & $<0.001$ & $<0.001$ & $<0.001$ \\
\hline
\end{tabular}

VFA, volatile fatty acids; A:P, acetate:propionate; SEM, standard error of the means.

* Means within a column differ from control $(\mathrm{p}<0.05)$.

of crude protein and the amount of NDF of the incubated diets ranged from 139 to $189 \mathrm{~g} / \mathrm{kg}$ dry matter and 160 to $429 \mathrm{~g} / \mathrm{kg}$ dry matter, respectively. It appears that the effects of some metabolites of essential oils could depend on the type of diet used for in vitro incubation (Calsamiglia et al., 2007). Dietary NDF potentiated the effect of the ACEO on total VFA, whereas it counteracted the effects of the ACEO on acetate and propionate proportion and acetate:propionate ratio. Dietary crude protein potentiated the effect of ACEO on total VFA concentration, whereas it counteracted the effects of ACEO on molar proportions of propionate and butyrate and the acetate:propionate ratio (Klevenhusen et al., 2012).

The selection criteria to identify ACEO with positive effects on rumen microbial fermentation included decreased total methane production, decreased methane production per mole VFA, and simultaneously increased or no change in total VFA.

Eugenol is a phenylpropanoid and is one of the main compounds of clove (85\%) and cinnamon oils (Davidson and Naidu, 2000). Eugenol has been shown to have antimicrobial activity against gram-positive and gramnegative bacteria (Dorman and Deans, 2000). Castillejos et al. (2006) reported that eugenol $(500 \mathrm{mg} / \mathrm{L})$ modified the proportions of VFA (decreased propionate) without affecting total VFA. In the present study, a twofold higher dose of eugenol also decreased the proportion of propionate, but simultaneously decreased total VFA. In contrast, in a continuous culture study, a low dose of clove oil $(2.2 \mathrm{mg} / \mathrm{L})$ decreased the molar proportion of acetate and branchedchain VFA and increased the molar proportion of propionate (Busquet et al., 2005b). These differences suggest that results are distinctly dose-dependent.

Carvacrol, a monoterpenic phenol, is one of the major components of oregano and thyme oils. Phenolic compounds such as thymol, carvacrol, and eugenol have been shown to possess high antimicrobial activity owing to the presence of a hydroxyl group in the phenolic structure. Carvacrol manifested antimicrobial activity against gram- positive and gram-negative bacteria (Dorman and Deans, 2000). Benchaar et al. (2007) observed that when used at a concentration of $400 \mathrm{mg} / \mathrm{L}$, carvacrol did not have any effect on the total production of VFA but affected the molar proportions of VFA. In contrast, our findings showed that carvacrol $(1,000 \mu \mathrm{L} / \mathrm{L})$ strongly decreased total VFA and methane production but did not alter the molar proportion of VFA. This suggests that the antimicrobial activity of carvacrol may be too strong and nonspecific to improve rumen fermentation. A strong and nonspecific effect of carvacrol also was reported by Martínez-Fernández et al. (2013); in their study carvacrol $(40,80,160$, and $320 \mu \mathrm{L} / \mathrm{L})$ linearly decreased total VFA and total gas production.

Citral is a lemon-scented acyclic monoterpene aldehyde that occurs naturally in essential oils of citrus fruits (e.g., up to $5 \%$ in lemon oil) and in a variety of herbs and plants such as lemongrass (70\% to $80 \%)$ and eucalyptus (Jäger, 2009). Citral displayed moderate activity against gram-positive and gram-negative bacteria (Dorman and Deans, 2000). Treatment with 5,200 , and $500 \mathrm{mg} / \mathrm{L}$ mixtures of four ACEO (eugenol, carvacrol, citral, and cinnamaldehyde) with higher in two aldehyde-based compounds (citral, cinnamaldehyde) showed higher inhibitory effect on total VFA than phenolic-based mixtures, all combination also decreased methane production (Lin et al., 2013). In the present study, citral $(1,000 \mu \mathrm{L} / \mathrm{L})$ decreased methane production, but other effects (decreased VFA production and propionate proportion) were unfavorable. These results indicate lack of specificity of citral in methanogenesis.

Limonene is the most abundant monocyclic monoterpene in lemons, oranges, grapefruit, peppermint, spearmint, and other oils (Turner et al., 1999). Dorman and Deans (2000) demonstrated the antimicrobial activity of limonene, which was mainly against gram-negative bacteria. Castillejos et al. (2006) reported that limonene at 50 and $500 \mathrm{mg} / \mathrm{L}$ reduced total VFA concentration by $4.5 \%$ and $5.6 \%$, respectively. In our study, the high dose of limonene $(1,000 \mu \mathrm{L} / \mathrm{L})$ decreased methane production and had no effect on VFA production. However, the methane 
production expressed relative to VFA production did not differ from that of the control ( $p>0.05)$.

1,4-Cineole, a monoterpene cyclic ether, is known to be a major flavor constituent of lime (Citrus aurantiifolia) and Eucalyptus polybractea. According to Patra and Yu (2012), eucalyptus oil $(1 \mathrm{~g} / \mathrm{L})$ tended $(\mathrm{p}<0.1)$ to increase total VFA concentrations, decreased $(p<0.01)$ the molar proportion of acetate and propionate, and increased the molar proportion of butyrate. Eucalyptus oil also decreased methane production. In our study, 1,4-cineole did not affect VFA and decreased methane production. Methane production expressed relative to VFA production did not differ from the control $(p>0.05)$. These differences may be due to the synergistic effects of cineole and other ACEO in eucalyptus oil.

$\gamma$-Terpinene is a monoterpene and a major component of essential oils obtained from citrus fruits (Suzuki et al., 2004). There are no reports in the literature on the effects of $\gamma$-terpinene on rumen fermentation. Our results (Tables 2 and 3 ) indicate that $\gamma$-terpinene is not a potent rumen fermentation modifier.

$p$-Cymene is a monoterpene. In vitro studies have demonstrated that the $p$-cymene can be used as an antimicrobial against gram-positive and gram-negative bacteria (Custódio et al., 2011). Chaves et al. (2008) observed that $p$-cymene at a relatively low dose $(20 \mathrm{mg} / \mathrm{L})$ did not affect total VFA production or the proportion of VFA, but reduced methane production by $30 \%$. In contrast, a higher dose $(1,000 \mu \mathrm{L} / \mathrm{L})$ in our study did not affect methane production, but decreased VFA and propionate production and increased butyrate production, implying a dependence of the outcome on the dose used. These changes in fermentation would not be nutritionally beneficial to the host animal.

Linalool is a terpene alcohol. The highest concentration of linalool is found in the essential oil of Ocimum basilicum (up to 75\%) (Jäger, 2009). Linalool inhibits a wide spectrum of gram-positive and gram-negative bacteria (Dorman and Deans, 2000). Hristov et al. (2008) showed that Ocimum basilicum essential oil (10 and $100 \mathrm{mg} / \mathrm{L}) \mathrm{did}$ not affect total VFA or $\mathrm{pH}$ in in vitro incubation. The higher dose of linalool $(1,000 \mu \mathrm{L} / \mathrm{L})$ in our study decreased the production of methane, total VFA, and propionate proportion but increased butyrate proportion. Butyrate production also was increased after inclusion of eugenol, citral, and $p$-cymene. Higher production of butyrate after inclusion of essential oil and ACEO has also been shown in previous studies (Busquet et al., 2005a; Castillejos et al., 2006). The bacterium Butyrivibrio fibrisolvens is a major cultured butyrate-producing bacterium in the rumen (Stewart et al., 1997). However, this bacterial species is very sensitive to essential oils (McIntosh et al., 2003). Some cryptic butyrate-producing bacteria might be less sensitive to essential oils and contribute to the increased molar proportion of butyrate in the rumen cultures. Alternatively, predominant butyrate-utilizing bacteria might have been inhibited by essential oils or other fermentation products, such as hydrogen gas (Patra and Yu, 2012).

As expected, monensin decreased the concentration of methane and the proportion of butyrate but, unexpectedly, increased the proportion of acetate. According to Nagaraja et al. (1997) monensin decreased the acetate and butyrate proportions and increased the propionate proportion. Lower methane production after monensin treatment in the present study could be due to other effects of monensin (than decreased hydrogen availability owing to decreased acetate production), such as inhibition of hydrogen production from formate or depressing of ciliate protozoa (Nagaraja et al., 1997).

Bornyl acetate is a monoterpenic ester. Valeriana officinalis root oil is rich in bornyl acetate (up to 34\%) (Raal et al., 2007). García-González et al. (2008) demonstrated that Valeriana officinalis caused only negligible changes in ruminal fermentation in an in vitro screening assay. In contrast, bornyl acetate was the most promising agent in the present study. All doses of bornyl acetate $(500,1,000$, and $2,000 \mu \mathrm{L} / \mathrm{L})$ did not affect total VFA but methane production was reduced significantly. $\mathrm{Oh}$ et al. (1967) observed that bornyl acetate at 0.35 and 0.70 $\mathrm{mL} / \mathrm{L}$ moderately inhibited rumen microorganisms in sheep and deer. Positive effects of bornyl acetate on rumen fermentation in trial 2 were more pronounced than those of monensin. The results observed in trial 2 on the proportions of individual VFA suggest that the main effect of bornyl acetate consists of decreasing the acetate and butyrate proportions. The effect of bornyl acetate on the proportion of propionate was observed only at the highest concentration (Table 5). Dorman and Deans (2000) demonstrated that presence of an acetate moiety in the structure increased antimicrobial activity of the parent compound; in the case of borneol, bornyl acetate increased the antimicrobial activity against the tested microorganism. The overall VFA production in control in our study differed in each trial. In trial 1, the VFA production was more than $20 \%$ higher compared with control in trial 2 . The difference is probably related to the fact that in trial 2 one cow was in dry period and was fed ration with different composition (higher in roughage, lower in concentrate). As described Stewart et al. (1997) rumen bacteria vary greatly in their substrate specificity, and change in substrate may result in change of microbial community. Different microbial community composition could also influence effect of bornyl acetate on rumen fermentation, it seems that the effect of bornyl acetate $(1,000 \mu \mathrm{L} / \mathrm{L})$ in trial 1 was a bit stronger than the effect of higher dose $(2,000 \mu \mathrm{L} / \mathrm{L})$ of bornyl acetate in trial 2 . Different susceptibility of various 
bacterial strains to ACEO was described by Dorman and Deans (2000).

Pinene is a bicyclic monoterpene. There are two structural isoforms found in nature: $\alpha$ - and $\beta$-pinene. As the name suggests, both isoforms are important constituents of pine resin. One of the sources containing the highest concentrations of $\alpha$ - and $\beta$-pinene is the essential oil of the fruit of juniper (Juniperis communis) with a total content of over 80\% (Jäger, 2009). Chaves et al. (2008) showed that juniper oil $(20 \mathrm{mg} / \mathrm{L})$ decreased methane production in in vitro incubation by $49 \%$ and did not affect the total VFA production or molar proportion of individual VFA, which is consistent with our results: a high concentration of $\alpha$-pinene decreased methane production and did not affect VFA production. Furthermore, $\alpha$-pinene also is found in the essential oil of rosemary (Rosmarinus officinalis) (Jäger, 2009). Gunal et al. (2013) reported that rosemary essential oil $(125,250$, and $500 \mathrm{mg} / \mathrm{L})$ affected the molar proportion of VFA. In our study, neither $\alpha$-pinene nor $\beta$-pinene influenced VFA proportion, suggesting, that the different effects of a single ACEO compared with mixtures of ACEO in essential oils are probably due to synergistic effects of ACEO in essential oils.

In our study we did not measure nutrient digestibility, but nutrient digestibility positively correlate with VFA production (Getachew et al., 2004). From this point of view decreased VFA production after inclusion of all tested ACEO (with exception of bornyl acetate) suggests a reduction in nutrient digestibility. Reducing in in vitro dry matter and neutral detergent fibre digestibilities after inclusion high doses of ACEO has been reported previously (Benchaar et al., 2007).

\section{CONCLUSION}

In summary, this study showed that most of the ACEO evaluated in vitro significantly decreased methane production. However, from nine ACEO, that reduced the production of methane, five also decreased production of VFA. At the dose tested, only limonene, 1,4-cineole, bornyl acetate, and $\alpha$-pinene decreased methane production without adverse effects on VFA production, and only bornyl acetate reduced methane emission expressed per mol of VFA. Further research should elucidate if the reduction of methane production in bornyl acetate-treated rumen fluid also exists in vivo, and if this effect persists over a longer period.

\section{CONFLICT OF INTEREST}

We certify that there is no conflict of interest with any financial organization regarding the material discussed in the manuscript.

\section{ACKNOWLEDGMENTS}

This work was supported by the Ministry of Agriculture of the Czech Republic. Project MZERO0714.

\section{REFERENCES}

Agarwal, N., C. Shekhar, R. Kumar, L. C. Chaudhary, and D. N. Kamra. 2009. Effect of peppermint (Mentha piperita) oil on in vitro methanogenesis and fermentation of feed with buffalo rumen liquor. Anim. Feed Sci. Technol. 148:321-327.

AOAC. 1995. Official Methods of Analysis. 16th edn. Association of Official Analytical Chemists, Arlington, VA, USA.

AOAC. 2005. Official Methods of Analysis. 18th edn. Association of Official Analytical Chemists, Arlington, VA, USA.

Beauchemin, K. A., M. Kreuzer, F. O'Mara, and T. A. McAllister. 2008. Nutritional management for enteric methane abatement: A review. Aust. J. Exp. Agric. 48:21-27.

Benchaar, C., A. V. Chaves, G. R. Fraser, K. A. Beauchemin, and T. A. McAllister. 2007. Effects of essential oils and their components on in vitro rumen microbial fermentation. Can. J. Anim. Sci. 87:413-419.

Busquet, M., S. Calsamiglia, A. Ferret, M. D. Carro, and C. Kamel. 2005. Effect of garlic oil and four of its compounds on rumen microbial fermentation. J. Dairy Sci. 88:4393-4404.

Busquet, M., S. Calsamiglia, A. Ferret, and C. Kamel. 2005. Screening for effects of plant extracts and active compounds of plants on dairy cattle rumen microbial fermentation in a continuous culture system. Anim. Feed Sci. Technol. 123124:597-613.

Calsamiglia, S., M. Busquet, P. W. Cardozo, L. Castillejos, and A. Ferret. 2007. Invited review: Essential oils as modifiers of rumen microbial fermentation. J. Dairy Sci. 90:2580-2595.

Castillejos, L., S. Calsamiglia, and A. Ferret. 2006. Effect of essential oil active compounds on rumen microbial fermentation and nutrient flow in in vitro systems. J. Dairy Sci. 89:2649-2658.

Castillejos, L., S. Calsamiglia, A. Ferret, and R. Losa. 2007. Effects of dose and adaptation time of a specific blend of essential oil compounds on rumen fermentation. Anim. Feed Sci. Technol. 132:186-201.

Chaves, A. V., M. L. He, W. Z. Yang, A. N. Hristov, T. A. Mcallister, and C. Benchaar. 2008. Effects of essential oils on proteolytic, deaminative and methanogenic activities of mixed ruminal bacteria. Can. J. Anim. Sci. 88:117-122.

Custódio, J. B. A., M. V Ribeiro, F. S. G. Silva, M. Machado, and M. C. Sousa. 2011. The essential oils component p -cymene induces proton leak through Fo-ATP synthase and uncoupling of mitochondrial respiration. J. Exp. Pharmacol. 3:69-76.

Davidson, P. M. and A. S. Naidu. 2000. Phyto-phenols. In: Natural Food Antimicrobial Systems (Ed. A. S. Naidu). CRC Press, Boca Raton, FL, USA. pp. 265-293.

Dorman, H. J. D. and S. G. Deans. 2000. Antimicrobial agents from plants: antibacterial activity of plant volatile oils. J. Appl. Microbiol. 88:308-316.

García-González, R., S. López, M. Fernández, R. Bodas, and J. S. González. 2008. Screening the activity of plants and spices for 
decreasing ruminal methane production in vitro. Anim. Feed Sci. Technol. 147:36-52.

Getachew, G., P. H. Robinson, E. J. DePeters, and S. J. Taylor. 2004. Relationships between chemical composition, dry matter degradation and in vitro gas production of several ruminant feeds. Anim. Feed Sci. Technol. 111:57-71.

Gunal, M., A. Ishlak, and A. A. Abughazaleh. 2013. Evaluating the effects of six essential oils on fermentation and biohydrogenation in in vitro rumen batch cultures. Czech $\mathrm{J}$. Anim. Sci. 558:243-252.

Hristov, A. N., J. K. Ropp, S. Zaman, and A. Melgar. 2008. Effects of essential oils on in vitro ruminal fermentation and ammonia release. Anim. Feed Sci. Technol. 144:55-64.

Jäger, W. 2009. Metabolism of terpenoids in animal models and humans. In: Handbook of Essential Oils:Science, Technology, and Applications (Eds. K. H. C. Baser and G. Buchbauer). CRC Press, Boca Raton, FL, USA. pp. 209-234.

Klevenhusen, F., A. Muro-Reyes, R. Khiaosa-ard, B. U. MetzlerZebeli, and Q. Zebeli. 2012. A meta-analysis of effects of chemical composition of incubated diet and bioactive compounds on in vitro ruminal fermentation. Anim. Feed Sci. Technol. 176:61-69.

Lin, B., J. H. Wang, Y. Lu, Q. Liang, and J. X. Liu. 2013. In vitro rumen fermentation and methane production are influenced by active components of essential oils combined with fumarate. J. Anim. Physiol. Anim. Nutr. 97:1-9.

Martínez-Fernández, G., L. Abecia, A. I. Martín-García, E. Ramos-Morales, G. Hervás, E. Molina-Alcaide, and D. R. Yáñez-Ruiz. 2013. In vitro-in vivo study on the effects of plant compounds on rumen fermentation, microbial abundances and methane emissions in goats. Animal 7:1925-1934.

McDougall, E. I. 1948. Studies on ruminant saliva: 1. The composition and output of sheep's saliva. Biochem. J. 43:99109.
McIntosh, F. M., P. Williams, R. Losa, R. J. Wallace, D. A. Beever, and C. J. Newbold. 2003. Effects of essential oils on ruminal microorganisms and their protein metabolism. Appl. Environ. Microbiol. 69:5011-5014.

Mertens, D. R. 2002. Gravimetric determination of amylasetreated neutral detergent fiber in feeds with refluxing in beakers or crucibles: collaborative study. J. AOAC Int. 85:1217-1240.

Nagaraja, T. G., C. J. Newbold, C. J. van Nevel, and D. I. Demeyer. 1997. Manipulation of ruminal fermentation. In: The Rumen Microbial Ecosystem (Eds. P. N. Hobson and C. S. Stewart). Springer, Dordrecht, Netherlands. pp. 523-632.

Oh, H. K., T. Sakai, M. B. Jones, and W. M. Longhurst. 1967. Effect of various essential oils isolated from douglas fir needles upon sheep and deer rumen microbial activity. Appl. Microbiol. 15:777-784.

Patra, A. K. and Z. Yu. 2012. Effects of essential oils on methane production and fermentation by, and abundance and diversity of, rumen microbial populations. Appl. Environ. Microbiol. 78:4271-4280

Raal, A., A. Orav, E. Arak, T. Kailas, and M. Müürisepp. 2007. Variation in the composition of the essential oil of Valeriana officinalis L. roots from Estonia. Proc. Estonian. Acad. Sci. Chem. 56:67-74

Stewart, C. S., H. J. Flint, and M. P. Bryant. 1997. The rumen bacteria. In: The Rumen Microbial Ecosystem (Eds. P. N. Hobson and C. S. Stewart). Springer, Dordrecht, Netherlands. pp. 10-72.

Suzuki, Y., H. Sakai, T. Shimada, M. Omura, S. Kumazawa, and T. Nakayama. 2004. Characterization of $\gamma$-terpinene synthase from Citrus unshiu (Satsuma mandarin). BioFactors 21:79-82.

Turner, G., J. Gershenzon, E. E. Nielson, J. E. Froehlich, and R. Croteau. 1999. Limonene synthase, the enzyme responsible for monoterpene biosynthesis in peppermint, is localized to leucoplasts of oil gland secretory cells. Plant Physiol. 120:879886. 